\title{
Sonographic parameters for assessment of fetal well-being in mid-gestation in german Thoroughbred mares
}

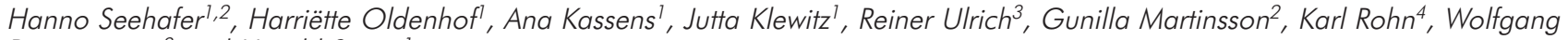 \\ Baumgärtner ${ }^{3}$ and Harald Sieme ${ }^{l}$ \\ 1 Clinic for Horses - Unit for Reproductive Medicine, University of Veterinary Medicine Hannover, Hannover, Germany \\ 2 National Stud Lower Saxony, Celle, Germany \\ 3 Department of Pathology, University of Veterinary Medicine Hannover, Hannover, Germany \\ 4 Institute of Biometry, Epidemiology, and Information Processing, University of Veterinary Medicine Hannover, Hannover, Germany
}

\begin{abstract}
Summary: Sonographic parameters were studied in healthy Thoroughbred mares $(n=286)$ in mid-gestation (day 84-232), and included: combined thickness of uterus and placenta (CTUP), echogenicity of the allantoic fluid (ALF), presence of free floating particles (FFP), and the fetal heart rate (FHR). In case of an abortion or stillbirth, data of the sonographic parameters were compared with results from necropsies. Abnormalities in CTUP values were seen in 18 cases (maximum value of $17.7 \mathrm{~mm}$ ). The sonographic appearance of ALF did not change during gestation. There was a significant difference in the presence of FFP with respect to the month of gestation. Abortion rates were determined to be 6.33 times higher for mares with presence of FFP. The mean FHR decreased significantly during gestation. In 7 mares a fetal bradycardia was found, while in 14 mares a tachycardia was found. Overall, 13 abortions (4.8\%) occurred between 201 and 315 days of gestation, which was about $94 \pm 46.1$ days after the sonographic examination. In one case of an abortion, an abnormal CTUP $(8.9 \mathrm{~mm})$, and in another case an abnormal FHR (170 beats/min) was determined. In the remaining 11 cases no abnormalities were detected during sonographic examinations. Although deviations from mean values for sonographic parameters do not necessarily result in an abortion or stillbirth, such abnormalities should be taken seriously and continuously monitored. We conclude that the month of gestation affects FFP as well as FHR in Thoroughbred mares. Furthermore, sonographic evaluation of CTUP, FFP, and FHR alone is not sufficient to foresee placental failure and impending abortion.
\end{abstract}

Keywords: horse / pregnancy / ultrasound / placentitis / combined thickness of uterus and placenta / abortion / reproduction

Citation: Seehafer H., Oldenhof H., Kassens A., Klewitz J., Ulrich R., Martinsson G., Rohn K., Baumgärtner W., Sieme H. (2015) Sonographic parameters for assessment of fetal well-being in mid-gestation in german Thoroughbred mares. Pferdeheilkunde 31, 477-484

Correspondence: Prof. Harald Sieme, Clinic for Horses - Unit for Reproductive Medicine, University of Veterinary Medicine Hannover, Bünteweg 15, 30559 Hannover, Germany, e-mail: harald.sieme@tiho-hannover.de

\section{Introduction}

Abortion and stillbirth can result in considerable economic losses for the owner of a broodmare. In addition, it can jeopardize the immediate and future health of the mare. It is, therefore, important to recognize mares with high-risk pregnancies in an early stage that an adequate treatment can be initiated, resulting in a successful birth, hopefully. Conditions that can cause high-risk pregnancies can be divided into causes affecting the mare (e.g. colic, lameness, infectious diseases), the foal (e.g. twins, malformation, arthrogryposis, malpresentation), as well as the placenta. The latter includes conditions like: infectious placentitis, placenta separation, umbilical abnormalities, hydrops allantois, and placental insufficiency (for review see: Santschi and Vaala 2011). Comparative studies exist in which the causes of abortion, stillbirth and perinatal death in horses were examined in retrospect (Giles et al. 1993, Hong et al. 1993). It was found that fetal mortality is most commonly the result of feto-placental infections. In case the etiologic agent is not known this is referred to as placentitis. The second most common cause for fetal mortality are complications at birth. Feto-placental well-being can be evaluated by transrectal and vaginal examination, transabdominal and transrectal ultrasonography, and hormonal analysis (Leblanc et al. 2004). Transabdominal ultrasonography can be performed starting from the 90th day of gestation. After this time, the uterus drops over the pelvic brim and can be visualized entirely from the ventral abdomen cranial to the udder (Troedsson and Sage 2001). Various parameters can be measured using ultrasound and threshold values for these have been determined, describing fetal health, both for clinical as well as field conditions. Such parameters include fetal orbital and aortic diameters, which describe fetal growth and development (Bucca et al. 2005). In addition, fetal heart rate (FHR) and fetal activity describe fetal viability (Bucca 2011). FHR measurements can be done using fetal electrocardiography, realtime B-mode ultrasonography using a stopwatch, and M-mode ultrasonography (Curran and Ginther 1995). Bucca (2011) reported a FHR at rest of $135 \pm 6.35$ beats $/ \mathrm{min}$ for month 4 of gestation, and values of $124 \pm 7.24$ for month $5,111 \pm 5.62$ for month 6, $109 \pm 5.58$ for month 7, and $104 \pm 6.14$ for month 8. During activity of the fetus, FHR values were $155 \pm 11.18$ beats/min for month 4 of gestation, $142 \pm 8.52$ for month 5, $139 \pm 11.72$ for month 6, $129 \pm 7.08$ for month 7 , and $125 \pm 11.54$ for the month 8 . Fetal heart rates that differ more than 2 times the standard deviation from the threshold values as indicated above were considered abnormal (Reef et al. 1996). Ultrasonographic parameters that are used to assess the fetal environment include the evaluation of the combined thickness of uterus and placenta (CTUP), and the echogenicity of fetal fluids including the existence of echogenic free floating particles. To measure the CTUP with transrectal ultrasound, a linear transducer is positioned cranial of the cervical-placental junction 
and moved in lateral direction until the middle branch of the uterine artery is visible ventral from the uterine body. The CTUP then is measured between the middle branch of the uterine artery and the allantoic fluid (Reef et al. 1995)). Measurement of the ventral part of the uterus was found to give more accurate information than when measurements were done of the dorsal part, because of the physiological edema in the dorsal part (Renaudin et al. 1997). When the CTUP is measured by transabdominal ultrasonography, areas of fetal contact should be avoided to prevent a compression of the uteroplacental unit (Bucca et al. 2005). An increased CTUP, detachment of the placenta from the endometrium, and increased echogenicity of the allantoic or amniotic fluids all may indicate placental failure or placentitis (Renaudin et al. 1997). Most often placentitis is induced by ascending infections through the cervix (Giles et al. 1993) and first ultrasonographic signs are seen next to the cervical star. For this reason, evaluation of CTUP by transrectal ultrasonographic examinations, seem to have a greater clinical value than transabdominal ultrasonographic examinations (Renaudin et al. 1997). For rectal examinations under clinical conditions, Renaudin et al. (1997) defined the following minimum sizes required for fetal well-being for ventral CTUP: $4.47 \mathrm{~mm}$ in month 4 of gestation, $3.81 \mathrm{~mm}$ in month $5,4.04 \mathrm{~mm}$ in month 6, 4.07 in month 7, and $4.69 \mathrm{~mm}$ in month 8 . In a study of rectal examinations under field conditions a ventral CTUP of up to $7 \mathrm{~mm}$ was considered normal when measured prior to the 300th day of gestation (Troedsson et al. 1997).

It is described that a sudden turbidity of fetal fluids may be caused by meconium, haemorrhage, or inflammatory debris. This may be an indication of fetal hypoxia, placental detachment or placental infection (Vaala and Sertich 1994). Presence of free floating particles (FFP) was found to be a normal finding in the allantois fluid from the fourth month of gestation to full term (Bucca et al. 2005, Renaudin et al. 1997). These particles consist of mucoproteins, calcium phosphate and other mineral deposits, and likely result from fetal kidney function (Bucca et al. 2005, Adams-Brendemueh/ and Pipers 1987). Often FFP are only visible after vigorous fetal movement (Reef et al. 1995).

The first aim of the study was the evaluation of upper and lower limits for sonographic parameters which describe fetal well-being. Parameters were assessed in Thoroughbred mares in mid-gestation and included: combined thickness of uterus and placenta (CTUP), echogenicity of the allantoic fluid (ALF), presence of free floating particles (FFP), and fetal heart rate (FHR). The second aim of our studies was to determine whether values for sonographic parameters could be used to predict particular complications during a pregnancy. Our studies included 286 healthy, pregnant Thoroughbred mares, and the sonographic evaluations were performed during mid-gestation (day 84-232 of gestation) under stud farm conditions.

\section{Material and methods}

\section{Animals and experimental design}

A total of 286 healthy, pregnant Thoroughbred mares were investigated. The study was performed on different stud farms in the mid-west of Germany. The day of gestation was derived from breeding records, and the mares examined were between 84-232 days pregnant. The mares were classified in the following groups: month 4 of gestation (84-120 days), month 5 of gestation (121-150 days), month 6 of gestation (151-180 days), month 7 of gestation (181-210 days), and month 8 of gestation (211-240 days). In addition, the mares were divided in groups according to their age $(<7,7-12$, $13-18,>18$ years of age) and parity (nulliparous, pluriparous $1-3 \times, 4-7 \times,>7 \times$ ). Informations about foaling, abortion, stillbirth and perinatal death were retrieved from breeding records. In the case of an abortion, the fetus and placenta were examined for pathogens and morphological abnormalities as demanded by the German Thoroughbred Breeders' Association. Fourteen mares were excluded from the study because of missing information about foaling.

In all cases, transrectal and transabdominal scans were performed by the same experienced person, while the mares were held in the box by an assistant at the halter. The total examination time per mare took about 3 minutes, including the removal of faeces or the application of isopropyl alcohol. Sonographic measurements were performed using a Logiqe ultrasound device (GE Healthcare, Solingen, Germany), equipped with a linear probe (I 739; 4 to $10 \mathrm{MHz}$ ) for transrectal and a convex probe (4C-RS; 2 to $5 \mathrm{MHz}$ ) for transabdominal examinations. The instrument settings used were held similar, for both transrectal and transabdominal ultrasonographic measurements. All examinations were recorded for a detailed evaluation later on. A total of 247 transrectal and 173 transabdominal examinations were analyzed.

\section{Ultrasonographic parameters to assess fetal well-being}

For transrectal examinations, the transducer was positioned at the cervical-placental junction as described by Reef et al. (10) and sonographic measurements were recorded. For assessments of ultrasonographic parameters, five sequence images were used. From these images, the combined thickness of uterus and placenta (CTUP) at the ventro-caudal aspect of the uterine body was measured, and the mean was calculated. A CTUP greater than $7 \mathrm{~mm}$ was considered abnormal (Troedsson et al 1997).

For transabdominal examinations, isopropyl alcohol was applied onto the ventral abdomen between udder and xiphoid. This served as a contact fluid for sonographic visualization. A recording of the entire fetus was taken and the fetal heart rate (FHR) was counted by using a stopwatch. The following FHR values were considered normal: 122-177 beats/min for month 4 of gestation, 110-159 beats/min for month 5, 106-163 beats/min for month 6, 98-143 beats/min for month 7, and 91-148 beats/min for month 8 (Curran and Ginther 1995).

The echogenicity of the intraluminal uterine fluid was evaluated using the grading system of McKinnon et al. (1988), where: Grade I = white (strongly echogenic or hyperechoic); Grade $\|$ = light grey (semi-echogenic or hyperechoic); Grade III = dark grey (hypoechoic-few hyperechoic foci suspended in anechoic medium); Grade IV=black (anechoic). The echogenicity of the ALF is considered abnormal when graded II to I (Renaudin et al. 1997). In addition to the echogenicity 
of the allantoic fluid, the presence or absence of free floating particles (FFP) was assessed by using a combination of transrectal and transabdominal sonographic images.

\section{Statistical analysis}

Statistical analyses were performed using SAS 9.3 software (SAS Institute Inc., Cary, NC, USA). Kruskal-Wallis-Tests were used to examine the effect of month of gestation, age and parity groups, on the assessed sonographic parameters. Fisher's tests were carried out to evaluate correlations between abortion and normal/abnormal CTUP, FHR, ALF values, the presence/absence of FFP, and maiden/multiparous mares. For correlating these parameters, the 'odds ratio' for the likelihood of an abortion was calculated. Results were expressed as means $\pm S D$. P-values $\leq 0.05$ were considered as significant.

\section{Results}

In Tables 1 and 2 data are presented of sonographic parameters as determined for mares grouped according to their age or parity number. No interactions were found between CTUP, FFP, FHR values and the age of the mare (P-values of $0.56,0.63$, and 0.27 , respectively) or parity (P-values of
$0.20,0.89$, and 0.45 , respectively). The echogenicity of the ALF was classified as grade III in all mares.

The mares examined did not exhibit clinical signs of ascending placentitis or infection (e.g. premature lactation and/or vaginal discharge) during mid-gestation.

Out of 272 mares, 259 gave birth to a living foal, meaning that $4.8 \%(n=13)$ of the mares underwent an abortion or lost their foal at birth. For these mares, the etiology and time of the fetal loss, as well as insights derived from necropsy reports were recovered and are listed in Table 3. For three mares the cause of the abortion was not known.

In the group of mares studied, there were 40 maiden mares, out of which one $(2.5 \%)$ had an abortion. In multiparous mares the abortion rate was $5.2 \%(n=12)$. No significant difference was found between the abortion rates as determined for maiden and multiparous mares.

Ventral rectal CTUP values as a function of the month of gestation were determined and are shown in Fig. 1. The minimum and maximum CTUP values were determined to be $2.4 \mathrm{~mm}$ and $17.7 \mathrm{~mm}$, respectively. CTUP values as determined between the fourth and eighth month of gestation did not exhibit significantly different values. There were 229 mares

Table 1 Values for sonographic parameters describing fetal well-being, as determined for mares grouped according to their age. The following sonographic parameters were assessed in Thoroughbred mares from the fourth to eighth month of gestation: combined thickness of uterus and placenta (CTUP), fetal heart rate (FHR), and presence of free floating particles (FFP). Means \pm SD are shown for the indicated numbers of mares in each group (n). No interactions were found between CTUP, FFP, FHR values and age of the mares $(p>0.05)$.

Werte ultrasonographischer Parameter zur Beurteilung der fetalen Gesundheit ermittelt bei Stuten in Abhängigkeit zum Alter. Die folgenden ultrasonographischen Parameter wurden bei Vollblutstuten zwischen dem 4. und 8. Trächtigkeitsmonat ermittelt: kombinierte Uterus- und Plazentadicke (CTUP), die fetale Herzfrequenz (FHR) und das Vorhandensein von frei fluktuierenden Partikeln (FFP, vorhanden/Total). Mittelwerte \pm SD für die Anzahl der Stuten in jeder Gruppe (n). Es wurden keine signifikanten Zusammenhänge zwischen den Werten von CTUP, FHR und FFP und dem Alter der Stute festgestellt werden ( $p>0.05)$.

\begin{tabular}{|c|c|c|c|c|}
\hline $\begin{array}{c}\text { age } \\
\text { (years) }\end{array}$ & $\begin{array}{c}\text { CTUP } \\
\text { mean } \pm \text { SD, }(n)\end{array}$ & $\begin{array}{c}F H R \\
\text { mean } \pm S D,(n)\end{array}$ & $\begin{array}{r}\text { FFP } \\
\text { present/to }\end{array}$ & otal, \% \\
\hline$<7$ & $5,0 \pm 1,73$ & $128 \pm 15,8$ & $34 / 56$ & 60,7 \\
\hline $7-12$ & $4,9 \pm 1,72(132)$ & $132 \pm 17,7$ & $88 / 135$ & 65,2 \\
\hline $13-18$ & $5,1 \pm 1,42$ & $127 \pm 16,9$ & $36 / 52$ & 69,2 \\
\hline$>18$ & $4,9 \pm 0,93$ & $116 \pm 15,8$ & $5 / 9$ & 55,6 \\
\hline
\end{tabular}

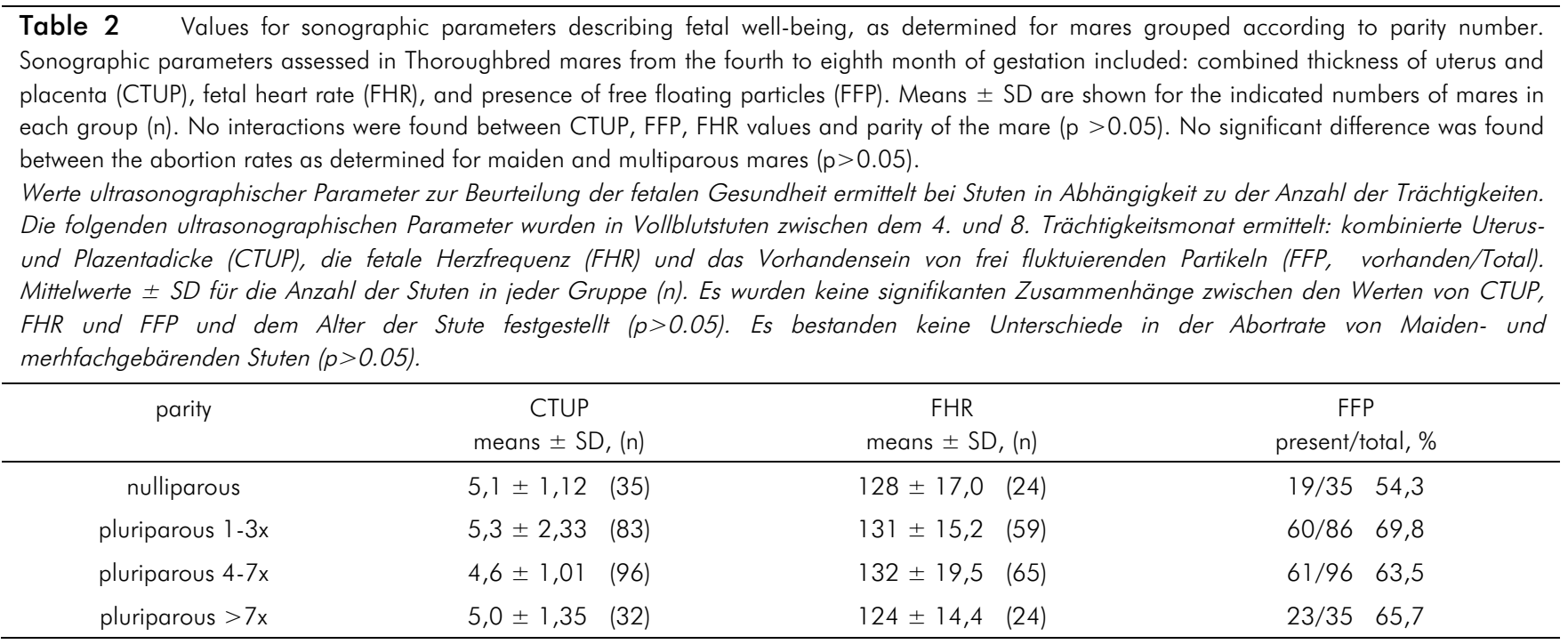


(92.7\%) with a normal CTUP of up to $7 \mathrm{~mm}$. Ten mares that had a normal CTUP underwent an abortion (4.4\%), whereas 1 out of 18 mares with an abnormal CTUP $(8.9 \mathrm{~mm}$ at day 194) aborted at 315 th day of gestation. This abortion was likely the result of a placentitis. Furthermore, in this case a moderate mineralization of the equine placenta was found. Four mares had a CTUP above $10 \mathrm{~mm}$ and all gave birth to a living foal. No significant differences were seen between abortion rates of mares with normal and abnormal CTUP. The 'odds ratio' to have an abortion was 1.2 times higher for

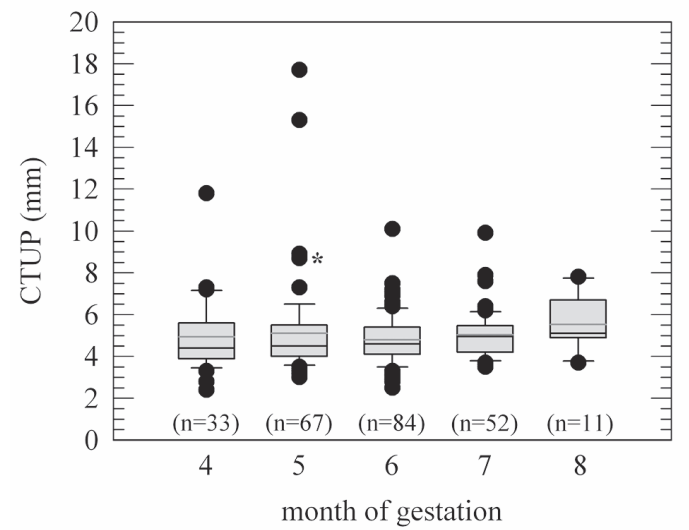

Fig. 1 Combined thickness of uterus and placenta (CTUP, $\mathrm{mm}$ ) as determined in thoroughbred mares from month 4 up to 8 of gestation. Box-and-whisker plots are shown, which illustrate the distribution of the data ( $n$ as indicated). The median and mean values are indicated with black and gray lines, respectively. The upper and mares with abnormal CTUP as compared to mares with a normal CTUP. In $24.7 \%(n=61)$ of the pregnancies there was a CTUP below the threshold values as described by others (Renaudin et al. 1997). In these cases, three mares had an abortion $(4.9 \%)$. The abortion rate for mares which had CTUP values above the thresholds was $4.3 \%(n=8)$, which was not significantly different from the rate as determined for mares with a CTUP below these thresholds. The 'odds ratio' to have an abortion was 0.86 times higher for mares with CTUP values above thresholds.

lower lines of the boxes represent the $25 \%$ and $75 \%$ percentiles, while the upper and lower whiskers represent the 5\% and 95\% percentiles. No significant differences in CTUP values were observed between pregnancy months. *: case in which an abortion took place; with an abnormal CTUP (above $7 \mathrm{~mm}$ ). No significant differences were seen between abortion rates of mares with normal and abnormal CTUP. The sonographic evaluation of CTUP alone is not sufficient to foresee placental failure and impending abortion.

Kombinierte Uterus- und Plazentadicke (CTUP) von Vollblutstuten im 4. bis 8. Trächtigkeitsmonat. Box-Whisker-Plots zeigen die Verteilung der Daten (n wie angegeben). Median und Mittelwerte sind jeweils mit schwarzen und graven Linien angegeben. Die oberen und unteren Striche der Boxen repräsentieren das 25\% und 75\% Perzentil, wohingegen die oberen und unteren Whisker das $5 \%$ und $95 \%$ Perzentil darstellen. Es wurden keine signifikanten Unterschiede in den CTUP Werten zwischen den Trächtigkeitsmonaten festgestellt. *: Fall, in dem ein Abort mit einem abnormalen CTUP (größer $7 \mathrm{~mm}$ ) stattfand. Es wurden keine signifikanten Unterschiede in der Abortrate von Stuten mit normalen und abnormalen CTUP Werten festgestellt. Ultrasonographische Abweichungen von den Grenzwerten der CTUP allein sind nicht ausreichend um Störungen der Plazentafunktion oder einen bevorstehenden Abort vorherzusehen.

Table 3 Values for the parameters as used for sonographic evaluation of fetal well-being (CTUP: combined thickness of uterus and placenta, ALF: echogenicity of the allantoic fluid, FFP: presence of free floating particles, FHR: fetal heart rate) as determined for pregnant Thoroughbred mares which aborted $(n=10)$. Sonographic evaluations were done during mid-gestation. In addition, findings from necropsies as performed after abortion are listed. It is possible that first indications of the pathological findings can be seen in the increased CTUP (8.9 mm at D 121 of gestation) but due to the large interval between examination and abortion, of 194 days, this can only be assumed.

Werte ultrasonographischer Parameter zur Beurteilung der fetalen Gesundheit (kombinierte Uterus- und Plazentadicke (CTUP in mm), Echogenität der Allantoisflüssigkeit (ALF als Grad), Vorhandensein von frei fluktuierenden Partikeln (FFP) und fetale Herzfrequenz (FHR in Schlägen/min)) ermittelt für tragende Vollblutstuten die im folgenden Trächtigkeitsverlauf abortierten (n=10). Die ultrasonographischen Untersuchungen wurden in der mittleren Trächtigkeit durchgeführt. Nachfolgend werden die Befunde der pathologischen Untersuchung nach einem Abort aufgelistet. Die in der Untersuchung erhöhte CTUP $(8,9 \mathrm{~mm}, \mathrm{D}$ 121) könnte ein Anzeichen für den bevorstehenden Abort gewesen sein, jedoch stellt der zeitliche Abstand von 196 Tagen bis zum Abort, diese Hypothese in Frage.

\begin{tabular}{|c|c|c|c|c|c|c|}
\hline \multicolumn{5}{|c|}{ findings obtained in mid-gestation } & \multicolumn{2}{|r|}{ findings following abortion } \\
\hline Day & CTUP $(\mathrm{mm})$ & ALF (grade) & FFP & FHR (beats/min) & Day & Necropsy of fetus and placenta \\
\hline 144 & 3.2 & 3 & + & 132 & 194 & cause unknown, no signs of infection \\
\hline 111 & 4.0 & 3 & - & / & 201 & cause unknown, no signs of infection \\
\hline 167 & / & / & / & 120 & 210 & cause unknown, no signs of infection \\
\hline 151 & 6.5 & 3 & + & / & 211 & infection with EHV 1 \\
\hline 180 & 5.3 & 3 & + & 120 & 248 & malformation, arthrogryposis \\
\hline 186 & 4.6 & 3 & + & 120 & 248 & cause unknown, no signs of infection \\
\hline 174 & 4.7 & 3 & + & 144 & 296 & vascular ischaemic or toxic placental insufficiency \\
\hline 201 & 4.2 & 3 & + & 170 & 297 & vascular ischaemic or toxic placental insufficiency \\
\hline 150 & 4.1 & 3 & + & / & 302 & bacteria induced placentitis \\
\hline 121 & 8.9 & 3 & + & / & 315 & placentitis with unknown etiologic agent \\
\hline
\end{tabular}


Echogenic FFP were observed in 164 mares (64.8\%), whereas FFP were absent in 89 mares. Mares with FFP had an abortion rate of $6.7 \%(n=11)$, whereas this was $1.1 \%$ $(n=1)$ for mares in which FFP were absent. The 'odds ratio' to have an abortion for mares with FFP was 6.3 times higher than for mares without FFP. Presence of FFP was found to exhibit significant differences between pregnancy months $(p=0.0032)$. Percentages of mares with FFP increased up to $78.1 \%$ in month 6 and decreased again to $45.5 \%$ in month 8 (Fig. 2).

FHR values as a function of the month of gestation were determined and are shown in Fig. 3. Maximum and minimum values of 220 and 90 beats/min, respectively, were determined. The mean FHR decreased significantly with the month of gestation ( $p=0.0127$ ). In 152 mares (87.9\%) a normal FHR was seen, from which 7 (4.6\%) lost their foal. For 7 mares the FHR was found to be below the reference value for the gestational age, while in 14 mares the FHR was above the threshold. From the group of mares with abnormal fetal heart rates (12.1\%), one mare (4.8\%) had an abortion. This fetus exhibited a FHR of 170 beats/min at day 297 of gestation. The etiologic cause of this abortion was a placental insufficiency with a vascular ischaemic or toxic etiology. No significant differences were found between abortion rates for mares with normal and abnormal FHR values. The 'odds ratio' to have an abortion was for mares with abnormal FHR 0.98 times higher than for mares with normal FHR.

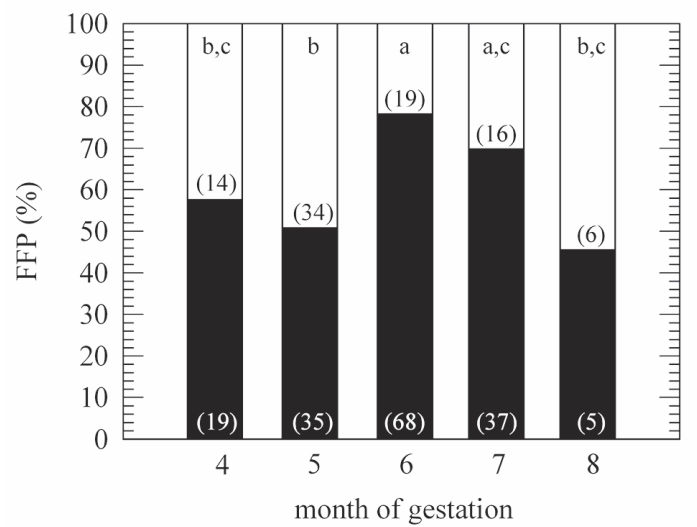

Fig. 2 Presence () and absence () of free floating particles (FFP) in placental fluids as determined in Thoroughbred mares from month 4 up to 8 of gestation. Significant differences for the presence of FFP between pregnancy months are indicated by different letters ( $a-c$, with $P<0.05)$. Mares with presence of FFP had an abortion rate of $6.7 \%(n=11)$, whereas this was $1.1 \%(n=1)$ for mares in which FFP were absent. The 'odds ratio' to have an abortion for mares with FFP was 6.3 times higher than for mares without FFP. However, the sonographic evaluation of FFP alone is not sufficient to foresee placental failure and impending abortion.

Vorhandensein () und Fehlen () von frei fluktuierenden Partikeln (FFP) im Fruchtsack von Vollblutstuten im 4. bis 8. Trächtigkeitsmonat. Es wurden signifikante Unterschiede im Vorkommen von FFP in Abhängigkeit zu den Trächtigkeitsmonaten ermittelt und im folgenden mit unterschiedlichen Buchstaben gekennzeichnet ( $a-c$, mit $P$ $<0,05)$. Stuten mit FFP hatten eine Abortrate von 6,7\% $(n=11)$, wohingegen bei Fehlen von FFP eine Stute abortierte $(1,1 \%)$. Das Chancenverhältnis für einen Abort war für Stuten mit FFP 6,3 mal höher als für Stuten ohne. Die ultrasonographische Bestimmung von FFP allein ist nicht ausreichend um Störungen der Plazentafunktion oder einen bevorstehenden Abort vorherzusehen.

\section{Discussion}

In this study, sonographic parameters were used to evaluate fetal well-being under field conditions. Parameters studied included: the combined thickness of uterus and placenta (CTUP) by transrectal scans, the fetal heart rate (FHR) by transabdominal ultrasonography, and the echogenicity of the allantoic fluid and presence of echogenic free floating particles (FFP) in the allantoic fluid as assessed by using a combination of both techniques mentioned above. The obtained data were compared to those of previous clinical studies on threshold values for fetal well-being. In the case of an abortion or stillbirth, the etiological cause was investigated and it was looked for whether the collected sonographic parameters did correlate. Differences were not found between the abor-

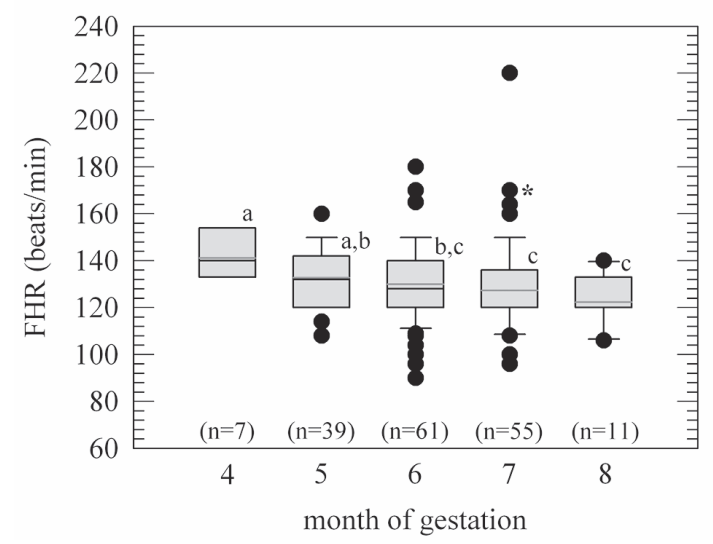

Fig. 3 Fetal heart rate (FHR, beats/ $\mathrm{min}$ ) as determined in Thoroughbred mares from month 4 up to 8 of gestation. Box-and-whisker plots are shown, which illustrate the distribution of the data (n as indicated). The median and mean values are indicated with black and gray lines, respectively. The upper and lower lines of the boxes represent the $25 \%$ and $75 \%$ percentiles, while the upper and lower whiskers represent the $5 \%$ and $95 \%$ percentiles. Significant differences in mean FHR values between months are indicated with different letters (a-c, with $\mathrm{P}<0.05)$. *: case in which an abortion took place; with an abnormal FHR (of 170 beats/min). No significant differences were found between abortion rates for mares with normal and abnormal FHR values. In 7 mares a fetal bradycardia was found, while in 14 mares a tachycardia was found. From the group of mares with abnormal fetal heart rates (12.1\%), one mare (4.8\%) had an abortion. The sonographic evaluation of FHR alone is not sufficient to foresee placental failure and impending abortion.

Die ermittelte fetale Herzfrequenz (FHR in Schlägen/min) von Vollblutstuten im 4. bis 8. Trächtigkeitsmonat. Box-Whisker-Plots zeigen die Verteilung der Daten (n wie angegeben). Median und Mittelwerte sind jeweils mit schwarzen und graven Linien angegeben. Die oberen und unteren Striche der Boxen repräsentieren das 25\% und $75 \%$ Perzentil, wohingegen die oberen und unteren Whisker das 5\% und 95\% Perzentil darstellen. Es wurden signifikante Unterschiede der mittleren FHR in Abhängigkeit zu den Trächtigkeitsmonaten ermittelt und im folgenden mit unterschiedlichen Buchstaben gekennzeichnet (a-c, mit $P<0,05)$. *: Fall, in dem ein Abort mit einer abnormalen FHR (von 170 Schlägen/min) stattfand. Es wurden keine signifikanten Unterschiede in der Abortrate von Stuten mit normalen und abnormalen FHR Werten festgestellt. In 7 Fällen wurde eine fetale Bradykardie und in 14 Fällen eine fetale Tachykardie gemessen. Aus der Gruppe der Stuten mit einer abnormalen FHR $(12,1 \%)$ kam es bei einer Stute zu einem Abort (4,8\%). Ultrasonographische Abweichungen von den Grenzwerten der FHR allein sind nicht ausreichend um Störungen der Plazentafunktion oder einen bevorstehenden Abort vorherzusehen. 
tion rates of maiden and multiparous mares. This is in agreement with the findings of others (Platt 1973).

CTUP values as determined in our studies are comparable with those obtained by others under field conditions (Troedsson et al. 1997, Colon 2008). CTUP values under field conditions are slightly higher as those collected under clinical conditions (Renaudin 1997). In our study, only $24.7 \%$ of the mares had a CTUP below $95 \%$ of the confidence interval of mares under comparable conditions. This is in agreement with the findings of Troedsson et al. (1997), who found that more than half of the mares had a CTUP above $7 \mathrm{~mm}$ prior to day 300. In our studies, mares with a physiological CTUP had an abortion rate of $4.4 \%$ (10 out of 229). Furthermore, $7.3 \%$ (18 out of 247 mares) showed a CTUP above $7 \mathrm{~mm}$ from which only one had an abortion (5.6\%). In this case a CTUP of $8.9 \mathrm{~mm}$ was determined at day 121 of gestation, and the abortion took place 194 days later. The pathological examination revealed a placentitis and a moderate mineralization of the placenta. The observed increased CTUP, at an earlier stage, could have been an indication for this. Colon (2008) reported that for 16 mares which were diagnosed with abnormal (increased) CTUP between 270 and 330 days gestation, treatment with trimethoprim-sulfamethoxazole, pentoxifylline and altrenogest until foaling resulted in pregnancies to term and live foal delivery.

In our studies, the echogenicity of the ALF was found not to change from the fourth to eighth month of gestation, and was classified as grade III in all cases. Grade III is considered to be physiological. These results are similar to results of others (Renaudin 1997). A turbidity of fetal fluids was not seen. Such turbidity can be the result of meconium, haemorrhage, or inflammatory debris and may be an indication of fetal hypoxia, placental detachment or placental infection (Vaala and Sertich 1994).

The number of mares with presence of FFP was found to significantly increase up to $78.1 \%$ in month 6 and decreased again to $45.4 \%$. The presence of FFP in the allantoic fluid has been described from the fourth month of gestation to full term (Bucca et al. 2005, Renaudin 1997). It should be noted, however, that FFP are often only visible after vigorous fetal movement (Reef et al. 1996). An increase in number of FFP has been reported in case of placentitis (Vaala and Sertich 1994, Renaudin et al. 1999). The evaluation of FFP quantities is difficult, when sonographic measurements are short. Frequently it was found that the fetus was inactive during the examination and therefore the presence of FFP was not easily detected. In order to assess if abortion rates are indeed higher for mares with than for mares without FFP, assessment of the quantity of particles during fetal activity (with longer sonographic examinations) could help evaluate fetal well-being.

Measurement of FHR can be performed by fetal electrocardiography, realtime B-mode ultrasonography using a stopwatch, and M-mode ultrasonography. Curran and Ginther (1995) did not find significant differences between the FHR values as determined using $\mathrm{M}$-mode or B-mode ultrasonography from the third to sixth month of gestation. After the third month of pregnancy, FHR was slow enough for counting in B-mode ultrasonography using a stopwatch. FHR values as determined in this study are comparable with those documented elsewhere for Thoroughbred (Kähn and Leidl 1987) as well as Standardbred mares (Bucca et al. 2005). The large variation in FHR values in our studies is in accordance with the observations of others (Kähn and Leidl 1987). Such large variation can be explained by the lack of discrimination between active and inactive phases of the fetus (Bucca et al. 2005, Bucca 2011). The mean FHR was found to significantly decrease with the month of gestation. In our studies, we found that 152 mares (87.8\%) exhibited a normal FHR, while in 21 mares $(12.1 \%)$ abnormal fetal heart rates were seen. In 7 mares a fetal bradycardia was found, while in 14 mares a tachycardia was detected. For only one mare with an abnormal FHR (4.8\%) an abortion was seen (FHR of 170 beats/ min at day 297 of gestation). The etiologic cause of this abortion was a placental insufficiency with a vascular ischaemic or toxic background. These pathological findings likely do not explain the tachycardia, since this was observed 96 days before the abortion. We did not observe significant differences between abortion rates of mares with normal and abnormal FHRs. Colles et al. (1978) reported that persistent tachycardia serves as an indication to continue monitoring, although it not necessarily indicates fetal distress. Marked or progressive bradycardia, however, may have a more serious prognosis.

From the group of mares which lost their foal, 5 mares underwent an abortion within 68 days. In three cases the cause of the abortion was unknown, while in the case of the other abortions one mare had an infection with equine herpersvirus-1 and one exhibited fetal malformation and arthrogryposis. For these mares, no abnormalities in their sonographic examinations were seen. The increased CTUP of $8.9 \mathrm{~mm}$ detected on day 121 of gestation in one mare which underwent an abortion at day 315 day could be correlated with the placentitis and moderate mineralization of the placenta which was seen. In such cases, continuous sonographic monitoring should be performed to reveal further developments. This allows for initiation of treatments with antibiotics, anti-inflammatory drugs and altrenogest in time for minimization of fetal losses (Macpherson and Bailey 2008). Sonographic evaluations have been proposed for efficiently diagnosing ascending placentitis, prior to the development of overt clinical symptoms (e.g. premature lactation and vaginal discharge). Furthermore, in case of experimentally induced placentitis, treatment with trimethoprim sulfamethoxazole, pentoxifylline and altrenogest did not result in altered CTUP values, as compared to non-treated mares (Bailey et al. 2010). These and our findings are in good agreement with the results of Brazilian authors (Souza et al. 2010), who concluded that CTUP measurement alone is not sufficient to foresee placental failure and impending abortion.

Although parameters derived from sonographic evaluations during mid-gestation of Thoroughbred mares have been implicated in describing the level of fetal stress and increased risks for pregnancy failure, data from this study indicate that values of such parameters deviating from reference data can result in full term pregnancies. We conclude that the month of gestation affects FFP as well as FHR in Thoroughbred mares. Furthermore, the sonographic evaluation of CTUP, FFP, and FHR alone is not sufficient to foresee placental failure and impending abortion. 


\section{Abbreviations}

CTUP - combined thickness of uterus and placenta

ALF - echogenicity of allantoic fluid

FFP - free floating particles

FHR - fetal heart rate

\section{Authors' contributions}

Harald Sieme and Hanno Seehafer designed the study. Hanno Seehafer and Harald Sieme performed the research and wrote the manuscript. All authors were involved in discussing and interpreting the data described in this study, critically read the manuscript, and approved the final version of the manuscript.

\section{Animal Welfare Statement}

The study was authorized by LAVES (Niedersächsisches Landesamt für Verbraucherschutz und Lebensmittelsicherheit). Registration number 33.9-42502-05-12A246

\section{Acknowledgement}

This study was kindly supported by the Fährhof Foundation

\section{References}

Santschi E. M., Vaala W. E. (2011) Identification of high-risk pregnancy. In: McKinnon A. O., Squires E. L., Vaala W. E., Varner D. D. (eds.), Equine Reproduction 2nd Edition. Ames: Wiley-Blackwell, 5-15

Giles R. C., Donahue J. M., Hong C. B., Tuttle P. A., Petrites-Murphy M. B., Poonacha K. B., Roberts A. W., Tramontin R. R., Smith B., Swerczek T. W. (1993) Causes of abortion, stillbirth, and perinatal death in horses: 3,527 cases (1986-1991). J. Am. Vet. Med. Assoc. 203, 1170-1175

Hong C. B., Donahue J. M., Giles R. C., Petrites-Murphy M. B., Poonacha K. B., Roberts A. W., Smith B. J., Tramontin R. R. Tuttle P. A., Swerczek T. W. (1993) Etiology and Pathology of Equine Placentitis. J. Vet. Diagn. Invest. 5, 56-63

Leblanc M. M., Macpherson M., Sheerin P. (2004) Ascending placentitis: what we know about pathophysiology, diagnosis, and treatment. In: Proceedings of the 50th Annual Convention of the American Association of Equine Practitioners, Denver, USA. P1417.1204

Troedsson M. H. T., Sage A. M. (2001) Fetal/Placental Evaluation in the Mare. In: Ball BA (ed.), Recent Advances in Equine Reproduction, Int. Vet. Inform. Serv. (www.ivis.org); 2001; Ithaca NY, USA

Bucca S., Fogarty U., Collins A., Small V. (2005) Assessment of fetoplacental well-being in the mare from mid-gestation to term: transrectal and transabdominal ultrasonographic features. Theriogenology 64, 542-557

Bucca S. (2011) Ultrasonographic monitoring of the fetus. In: McKinnon A. O., Squires E. L., Vaala W. E., Varner D. D. (eds.), Equine Reproduction 2nd Edition. Ames: Wiley-Blackwell, 39-54

Curran S., Ginther O. J. (1995) M-mode ultrasonic assessment of equine fetal heart rate. Theriogenology 44, 609-617

Reef V. B., Vaala W. E., Worth L. T., Sertich P. L., Spencer P. A. (1996) Ultrasonographic assessment of fetal well-being during late gestation: development of an equine biophysical profile. Equine Vet. J. 28, 200-208

Reef B., Vaala E., Worth T., Hammett B. (1995) Ultrasonographic evaluation of the fetus and intrauterine environment in healthy mares during late gestation. Vet. Radiol. Ultrasound 36, 533-54 1 
Renaudin C., Troedsson M. H. T., Gillis C. L., King V. L., Bodena A. (1997) Ultrasonographic evaluation of the equine placenta by transrectal and transabdominal approach in the normal pregnant mare. Theriogenology 47, 559-573

Troedsson M. H. T., Renaudin C., Zent W., Steiner J. (1997) Transrectal ultrasonography of the placenta in normal mares and mares with pending abortion: a field study. In: Proceedings of the 43rd Annual Convention of the American Association of Equine Practitioners, Phoenix, USA, 256-258

Vaala W. E., Sertich P. L. (1994) Management strategies for mares at risk for periparturient complications. Vet. Clin. North Am. Equine Pract. 10, 237-265

Adams-Brendemueh/ C., Pipers F. S. (1987) Antepartum evaluations of the equine fetus. J. Reprod. Fertil. 35 (Suppl), 565-573

McKinnon A. O., Squires E. L., Pickett B. W. (1988) Uterine pathology. In: Equine Reproductive Ultrasonography. Animal Reproduction Laboratory, Bulletin No 04, Colorado State University, Fort Collins, 31-40

Platt H. (1973) Aetiological aspects of abortion in the Thoroughbred mare. J. Comp. Pathol. 83, 199-205

Colon J. L. (2008) Trans-Rectal ultrasonographic appearance of abnormal combined utero-placental thickness in late-term gestation and its incidence during routine survey in a population of Thoroughbred mares (2005-2008). In: Proceedings of the 54th Annual Convention of the American Association of Equine Practitioners, San Diego, USA. 279-285

Renaudin C., Liu I., Troedsson M. H. T, Schrenzel M. (1999) Transrectal ultrasonographic of ascending placentitis in the mare: a report of two cases. Equine Vet. Educ. 11, 69-74

Kähn W., Leidl W. (1987) Die Ultraschall-Biometrie von Pferdefeten in utero und die sonographische Darstellung der Organe. Disch. Tierärztl. Wsch. 94, 509-515

Colles C. M., Parkes R. D., May C. J. (1978) Foetal electrocardiography in the mare. Equine Vet. J. 10, 32-37

Macpherson M. L., Bailey C. S. (2008) Treating the mare with placentitis: a clinical approach. J. Equine Vet. Sci. 28, 703-708

Bailey C. S., Macpherson M. L., Pozor M. A., Troedsson M. H. T., Benson S., Giguere S., Sanchez L. C., LeBlanc M. M., Vickroy T. $W$. (2010) Treatment efficacy of trimethoprim sulfamethoxazole, pentoxifylline and altrenogest in experimentally induced equine placentitis. Theriogenology 74, 402-412

Souza A. M., Winter G. H. Z., Garbade P., Wolf C. A., Jobim M. I. M., Gregory R. M., Mattos R. C. (2010) Ultrasonographic evaluation of the Criollo mare placenta. Anim. Reprod. Sci. 121, 320-321

\section{Erweiterte Zusammenfassung}

\section{Sonographische Parameter}

zur Beurteilung der fetalen Vitalität bei fortgeschritten tragenden Stuten

\section{(4.-8. Trächtigkeitsmonat) der deutschen Vollblutzucht}

Untersuchungen zur Feststellung der Konzeption bei der Stute werden in der frühen Gravidität per rekto-manueller Exploration und ergänzender transrektaler Sonographie durchgeführt. In den letzten Jahren kommen zusätzlich, bei immer mehr Pferdezuchtbetrieben, Untersuchungen im Herbst hinzu, um den Fortbestand der Gravidität zu bestätigen. Untersuchungen im Herbst (September) werden routinemäßig bei allen Vollblutstuten in Deutschland durchgeführt und stellen seit Jahrzehnten einen etablierten Baustein in der deutschen Vollblutzucht dar. Die zu diesem Zeitpunkt durchgeführten Untersuchungen dienen nicht nur der reinen Feststellung der
Trächtigkeit, sondern liefern zudem Informationen über den Gesundheitsstatus des Fetus, der Stute und des Standortes. Für die Beurteilung der fetalen Gesundheit wurden in den letzten Jahrzehnten verschiedene Parameter validiert. Einige dieser Parameter sollten in ihrer Aussagekraft an einer großen Anzahl von Stuten unter Feldbedingungen überprüft werden. In diesem Zusammenhang wurden zur Beurteilung der fetalen und maternalen Gesundheit von Stuten in der mittleren Trächtigkeit (84-232 Trächtigkeitstag) Ultraschallaufnahmen von gesunden Vollblutstuten $(n=286)$ ausgewertet und die kombinierte Uterus- und Plazentadicke (CTUP), die Echogenität der Allantoisflüssigkeit (ALF), das Vorhandensein von frei fluktuierenden Partikeln (FFP) und die fetale Herzfrequenz (FHR) bestimmt und mit Normalwerten aus der Literatur verglichen. In den Fällen eines Abortes oder einer Totgeburt wurde die Ätiologie ermittelt und mit Hilfe der erhobenen sonographischen Parameter mögliche Fruherkennungsparameter überprüft. In der Studie konnten keine Unterschiede in der Abortrate von Maiden- und merhfachgebärenden Stuten gefunden werden. Eine Überschreitung der physiologischen CTUP Werte von $7 \mathrm{~mm}$ (Troedsson et al. 1997) konnte in 18 Fällen beobachtet werden, mit einer maximalen Plazentadicke von 17,7 mm. Die Geburtenrate dieser Stuten unterschied sich mit 94,4\% nicht signifikant von der Gesamtheit der Stuten (95,2\%). Die Echogenität der ALF änderte sich im Laufe der Trächtigkeit nicht und wurde in allen Fällen mit Grad III klassifiziert, welcher als physiologisch gesehen wir (Renaudin et al. 1997). Das Vorkommen von FFP unterschied sich signifikant zwischen den Trächtigkeitsmonaten. Frei fluktuierende Partikel werden in der Alantoisflüssigkeit vom 4. Monat an bis zur Geburt als physiologisch beschrieben (Bucca et al. 2005, Renaudin et al. 1997), wobei ein starker Anstieg der FFP als mögliches Anzeichen einer Plazentitis zu sehen ist (Vaala und Sertich 1994, Renaudin et al. 1999). Das Vorkommen stieg bis zum 6. Trächtigkeitsmonat signifikant auf $78,1 \%$ an und sank folgend auf $45,4 \%$ ab. Die Abortraten von Stuten bei denen FFP dargestellt werden konnten waren 6,33 höher als bei Stuten ohne FFP. Die mittlere FHR sank signifikant mit den Trächtigkeitsmonaten. In 7 Fällen wurde eine fetale Bradykardie und in 14 Fällen eine fetale Tachykardie gefunden. Von diesen Stuten abortierte eine $(4,5 \%)$ im letzten Trimenon mit einer FHR von 170 Schlägen/min zum Untersuchungszeitpunkt. Insgesamt kam es zu 13 Aborten (4,8\%) zwischen dem 201. und 315. Trächtigkeitstag, welche im Mittel $94 \pm 46,1$ Tage nach der Ultraschalluntersuchung lagen. In einem Abortfall wurde eine abnormale CTUP $(8,9 \mathrm{~mm})$ in einem anderen Fall eine abnormale FHR (170 Schläge/min) zum Zeitpunkt der Untersuchung festgestellt. In den verbleibenden 11 Fällen wurden keine Abweichungen von den Grenzwerten der ultrasonographischen Parameter erkannt. Obwohl abnormale Grenzwerte nicht zwangsweise zu Aborten und Totgeburten führen, sollten Abweichungen erstgenommen und die Stuten überwacht werden. Zusammenfassend kann gesagt werden, dass der Trächtigkeitsmonat das Vorkommen von FFP und die FHR bei Vollblutstuten beeinflusst. Des Weiteren schlussfolgern wir, dass eine ultrasonographische Auswertung von CTUP, FFP und FHR allein nicht aussagekräftig ist um plazentäre Probleme oder einen bevorstehenden Abort vorherzusehen.

Schlüsselwörter: Stute / Trächtigkeit / Ultraschall / Placentitis / kombinierte Dicke von Uterus und Plazenta / Abort / Reproduktion 